\title{
CASE STUDIES IN ENGINEERING AND TECHNOLOGY INNOVATION IN THE CARIBBEAN: A FOCUS ON EDUCOLCOM AND BEVCOM
}

\author{
Jason R. Rameshwar ${ }^{1 *}$ and Graham S. King ${ }^{2}$ \\ ${ }^{1,2}$ Faculty of Engineering, The University of the West Indies, Trinidad \\ ${ }^{1}$ Email: jrameshwar@gmail.com*(Corresponding author) \\ 2Email: graham.king@ sta.uwi.edu
}

\begin{abstract}
Caribbean SMEs (EduColCom and BevCom) identified Industry 4.0 (I4.0) enabling technologies integrating areas of their value networks. This enabled them to be innovative, competitive and sustainable within the global marketplace. This paper illustrated Proof of Concept examples of I4.0 technologies and overcoming implementation challenges by horizontally integrating with a vendor.

Structured interviews with C-level executives determined each SME's I4.0 developmental readiness and the methods used to select and adopt new technologies. Their strategies were based on the existing stability of each system and reinforced the need of C-level support for transformation. Their evolution roadmaps can be duplicated by other SMEs to achieve similar improvements.
\end{abstract}

Keywords: Competitiveness, Evolution Roadmap, Industry 4.0, Innovation, SIDS SME. https://doi.org/10.47412/EBWB6632

\section{Introduction}

SMEs in Small Island Developing States (SIDS) must compete against global companies selling products and services to their local customer base. Internet retail allows any customer to purchase any product from any manufacturer or service provider in the global marketplace.

Island based economies share common features of having a small local market size (in comparison to larger continents as America and Europe), being surrounded by water which increases cost and time to reach larger markets (by requiring the use of sea and air transport) and having smaller manufacturing and production facilities than their larger global competitors (SMEs struggle to adequately compete with their economies of scale).

Thus, SMEs in Trinidad and Tobago, a twin-island republic in the Caribbean, continually compete globally even though physically restricted to the local geography.

Despite this, SMEs in SIDS can be competitive in the global marketplace through innovation to achieve and sustain their position. While technology can facilitate this goal, it can be costly to acquire and adopt. Given their small market base from which to gain revenue for investments, these organisations must be strategic in their approach.

C-level executives drive a company's strategy as they continually examine and evaluate internal and external factors affecting the business, process and customer. Strategies and technologies associated with 
Industry 4.0 (the common term for the current Forth Industrial Revolution) enable SMEs to achieve innovation, competitiveness and sustainability.

This paper examined two local SMEs, BevCom and EduColCom, in their use of I4.0 enabling technologies to derive strategic benefits that enabled them to sustain competitive positions in the global marketplace through continuous innovation and sustainability. The report illustrated this achievement through an understanding of Industry 4.0 (I4.0), identification of emerging technologies that enable I4.0 and its benefits, the methodology used to analyse the SMEs that identified their current and future technology investment and their strategic evolutionary roadmaps.

\section{Industry 4.0 (I4.0) and the Fourth Industrial Revolution (4IR)}

The term and concept of Industry 4.0 was publicised at the Hannover Fair in Germany in 2011, where it was introduced as Industrie 4.0 [1-3]. Five years later, the phrase "Fourth Industrial Revolution" was coined by Klaus Schwab [4]. Although a different terminology and wider focus, it shares many of the same key points as the earlier Industry 4.0 and is often used interchangeably [5 pp. 17-18].

However, the impact of the evolutionary change of I4.0 was first highlighted within the definition by the German Trade and Invest (GTAI) [1 p. 4]. The key foci were the phrases "paradigm shift", "product communicates with machinery" and "tell it exactly what to do". These terms outlined the change that I4.0 would initiate but that it would necessitate a technological change to facilitate them.

The synthesis of authors' descriptive assessments of I4.0 identified specific keywords that specify the key concepts of I4.0. Each is linked to their contributory I4.0 design principles [6 p. 12]:

- Evolution [of systems] [7, 8 p. 104; 9 p. 10; 10 p. 4] : Optimisation

- Connected systems $[1$ p. $5 ; 2$ p. $411 ; 9$ p. $10 ; 10$ p. $4 ; 11$ p. $1 ; 12$ p. $9 ; 13$ p. $12 ; 14$ p. $24 ; 15$ p. 6 ; 16 p. 1622] : Co-ordination of infrastructure and processes + Communication between all internal and external systems

- Decentralised [systems] [13 p. 13; 17 p. 6] : Decentralised

- Intelligent [systems] [3 p. 173; 9 p. 7; 12 p. 5; 13 p. 13] : Communication between all internal and external systems + Awareness of self + Knowing to provide feedback

- Integration of horizontal and vertical value chains [8 p. 174; 18 p. 38] : Integration + Coordination of infrastructure and processes + Communication between all internal and external systems

These key concepts led to the development of a comprehensive definition for Industry 4.0 that encompasses both the strategy and technological requirements needed to initiate change. Thus we define I4.0 as "the evolutionary change in decentralised connected systems to enable the intelligent integration of the horizontal and vertical value chains of the organisation" [19 pp. 11-12; 20 pp. 48-49; 21 p. 4].

\section{Emerging Technologies}

Technology facilitates evolution in a company so it can achieve the key concepts of I4.0. Enabling technologies for I4.0 include [7 p. 130; 15 p. $6 ; 22$ p. $2 ; 23$ p. $24 ; 24$ p. 5]:

- Machine learning

- Data mining

- Mobility technologies (mobile devices)

- Cloud computing

- Augmented reality and wearables

- Big Data analytics and advanced algorithms 
- Autonomous robots

- System integration

- Cybersecurity, authentication and fraud detection

- Internet of Things (IoT) platforms

- Simulation

- Additive manufacturing and 3-D printing

- Smart sensors

- Advanced human-machine interfaces

- Multilevel customer interaction and customer profiling (community)

- Location detection technologies

However, specific technology continues to change and this process from the beginning at the "innovation trigger" to the "plateau of productivity" outlines the path each technology takes throughout its lifecycle [25]. In 2019, the Gartner Hype Cycle identified strategic technology trends in the categories of intelligent, digital and mesh [26]. As illustrated in Table 30, each of the 2019 technologies are linked to different I4.0 enabling technologies. This was identified by evaluating each type of technology and the requirements needed for the application of the tool. This reinforced the concept that the choice of I4.0 enabling technology (or combination of technologies) is dependent upon the strategic focus of the need based on specific use cases. This aspect promotes evolution within various technologies as their modification is achieved by changing the integration of various enabling technologies.

Table 30: Gartner 2019 Technologies linked to I4.0 Enabling Technologies

\begin{tabular}{|c|c|}
\hline $\begin{array}{l}\text { Gartner } 2019 \\
\text { Technologies }\end{array}$ & Linked I4.0 Enabling Technologies \\
\hline Autonomous Things & Autonomous robots; Machine learning; Smart sensors \\
\hline $\begin{array}{l}\text { Augmented } \\
\text { Analytics }\end{array}$ & $\begin{array}{c}\text { Augmented reality and wearables; Data mining; Big Data analytics and } \\
\text { advanced algorithms; System integration; Simulation; Advanced human- } \\
\text { machine interfaces }\end{array}$ \\
\hline $\begin{array}{c}\text { AI-driven } \\
\text { Development }\end{array}$ & $\begin{array}{c}\text { Machine learning; Cloud computing; Data Mining; Big Data analytics and } \\
\text { advanced algorithms }\end{array}$ \\
\hline Digital Twin & $\begin{array}{l}\text { Data mining; Cloud computing; Big Data analytics and advanced algorithms; } \\
\text { System integration; Internet of Things platforms; Simulation; Smart sensors }\end{array}$ \\
\hline Empowered Edge & $\begin{array}{l}\text { Data mining; Big Data analytics and advanced algorithms; System Integration; } \\
\text { Internet of Things (IoT) platforms; Smart sensors }\end{array}$ \\
\hline $\begin{array}{l}\text { Immersive } \\
\text { Experience }\end{array}$ & $\begin{array}{l}\text { Data mining; Augmented reality and wearables; Big Data analytics and } \\
\text { advanced algorithms; System integration; Simulation; Smart sensors; Advanced } \\
\text { human-machine interfaces; Location detection technologies }\end{array}$ \\
\hline Blockchain & $\begin{array}{l}\text { Data mining; Cloud computing; Big Data analytics and advanced algorithms; } \\
\text { Cybersecurity, authentication and fraud detection; System integration }\end{array}$ \\
\hline Smart Spaces & $\begin{array}{l}\text { Machine learning; Data mining; Cloud computing; Augmented reality and } \\
\text { wearables; Big Data analytics and advanced algorithms; System integration; } \\
\text { Internet of Things (IoT) platforms; Smart sensors; Advanced human-machine } \\
\text { interfaces; Multilevel customer interaction and customer profiling (community); } \\
\text { Location detection technologies }\end{array}$ \\
\hline $\begin{array}{l}\text { Digital Ethics and } \\
\text { Privacy }\end{array}$ & $\begin{array}{c}\text { Machine learning; Cloud computing; Big Data analytics and advanced } \\
\text { algorithms; Cybersecurity, authentication and fraud detection; Multilevel } \\
\text { customer interaction and customer profiling (community) }\end{array}$ \\
\hline $\begin{array}{l}\text { Quantum } \\
\text { Computing }\end{array}$ & $\begin{array}{c}\text { Machine learning; Cloud computing; Big Data analytics and advanced } \\
\text { algorithms }\end{array}$ \\
\hline
\end{tabular}




\section{I4.0 Enabling Technology Benefits}

Each of the enabling technologies has the potential to move an organisation closer to adopting aspects of I4.0. The achievement of this goal is based upon derived benefits that accompany this transition.

An overview of the benefits of I4.0 was derived from an analysis of key phrases used by authors on the topic [7, 9, 27, 11-15, 17, 18, 23]. These benefits were categorised into three thematic groupings: business; process; and customer [19 pp. 33-35; 20 pp. 51-52; 21 p. 4] and arranged to highlight the similarities in benefits across the three groupings, as illustrated in Table 31. As highlighted by the dashed blocks, the common benefits to all are information, quality assurance and time (real-time and reduced loss time). This supports the impact of the I4.0 key concepts in driving change through the adoption of the enabling technologies thus facilitating incremental changes [28 p. 2954] as they evolve to satisfy the needs of the specific applications of the business, process and consumer.

Table 31: I4.0 Benefits and Opportunities

\begin{tabular}{|c|c|c|}
\hline Business & Process & Customer \\
\hline Information & Information & Information \\
\hline Quality assurance & Quality assurance & Quality assurance \\
\hline $\begin{array}{c}\text { Time (real-time and reduced } \\
\text { loss time) }\end{array}$ & $\begin{array}{l}\text { Time (real-time and reduced } \\
\text { loss time) }\end{array}$ & $\begin{array}{c}\text { Time (real-time and reduced } \\
\text { loss time) }\end{array}$ \\
\hline ---------Cōmpètitivive--------' & ---------Efficiènēȳ'--------- & 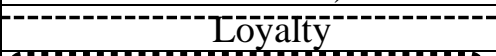 \\
\hline $\begin{array}{c}\text { Quantity independent price } \\
\text { model }\end{array}$ & Optimisation & $\begin{array}{l}\text { Quantity independent price: } \\
\text { model }\end{array}$ \\
\hline 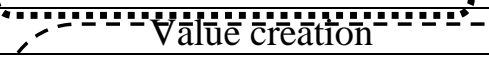 & 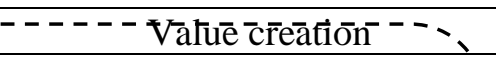 & 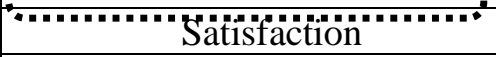 \\
\hline $\begin{array}{c}\text { Expense reduction and/or } \\
\text { minimisation }\end{array}$ & $\begin{array}{c}\text { Expense reduction and/or } \\
\text { minimisation }\end{array}$ & Growth \\
\hline Flexibility & Flexibility & \\
\hline Improvement & Improvement & \\
\hline Decentralisation & Decentralisation & \\
\hline Easily influenced & Easily influenced & \\
\hline Performance & Performance & \\
\hline Transparency & Transparency & \\
\hline Safety & Safety & \\
\hline New businesses & Reliability & \\
\hline New services & & \\
\hline Profit & & \\
\hline
\end{tabular}

The application of I4.0 enabling technologies through various levels of an organisation's value network achieves specific benefits associated with the interconnectedness throughout the levels B2C (Business to Consumer), B2B (Business to Business), Final Product, WIP (Work in Process), Raw Materials and Supplier. Tools used to strengthen connections between networks as well as create new linkages between disparate elements satisfy the connected and integration elements of the I4.0 key concepts.

\section{Methodology}

Research conducted in 2017 identified specific companies in Trinidad and Tobago that were developmentally ready to evolve to I4.0 [19]. Those SMEs identified current and planned investments in specific I4.0 enabling technologies without actively pursuing an I4.0 strategy. This study focused on two companies not previously interviewed. A beverage manufacturer, BevCom, and one that focuses on 
education with a strong emphasis on ICT systems, EduColCom, to understand their decision process and evaluate its linkages to I4.0.

Each company satisfied the same conditions, used in the original research [19 p. 39], as being registered as a business and operates in Trinidad and Tobago; produces manufactured goods with sales either $100 \%$ local or combined local and export; has the potential for customisation; and companies with whom the researcher has access to management for conducting interviews.

Although EduColCom is an educational facility, it adhered to the same system of production and manufacturing, in which the raw materials are the students with specific knowledge and competence levels. The transitional changes that occur throughout the academic life of each student represent WIP and the final output of finished products is graduate students with the ability to function in a work environment. B2B relationships are the links between the organisation and the work environments in which each graduate will ultimately function. B2C relationships involve providing end users ('consumers' that benefit from the skills of the graduates) with developed and maintained products and services (graduates). Entrepreneurial activities occur in direct linkages from Final Product (graduate) to the end user ('consumers').

To maintain consistency with the assessment performed in 2017, the original research instrument was administered to the C-level executives $[29$ p. $3 ; 30$ p. 84; 31 p. 86] as they had a clear understanding about their company's strategy and decision making factors that influenced the selection of the technologies being utilised. Assessments of their responses as well as a plant tour were used to analyse each company in terms of the I4.0 key concepts of evolution [of systems], connected systems, decentralised [systems], intelligent [systems], and integration of value chains, in order to identify the strongest areas and which enabling technologies are used.

\section{Technologies Identified for Current and Future Investment}

The need for specific technologies is driven by the goal to facilitate innovation, competitiveness and sustainability as each SME strives to achieve the benefits afforded by I4.0. The technologies adopted by BevCom (Table 32) and EduColCom (

Table 33) are summarised to demonstrate the purpose, benefits and integration of specific elements within their value chains. The relationship between each tool and the I4.0 enabling technologies highlighted in Table 34 show that each is comprised of fundamental subsets that demonstrate the evolution of emerging technologies.

Table 32: BevCom Technology Adoption

\begin{tabular}{|c|c|c|c|}
\hline Technology & Purpose & Benefits & Integration \\
\hline $\begin{array}{l}\text { Virtual } \\
\text { Reality } \\
\text { headsets }\end{array}$ & $\begin{array}{l}\text { Remote troubleshooting and } \\
\text { maintenance advice from } \\
\text { OEM }\end{array}$ & $\begin{array}{l}\text { Reduced equipment downtime; } \\
\text { Elimination of costs due to } \\
\text { transportation, meals and } \\
\text { accommodation for OEM's } \\
\text { technical specialist }\end{array}$ & $\begin{array}{c}\text { WIP } \\
\text { manufacturing } \\
\text { with equipment } \\
\text { Supplier } \\
\text { technical support }\end{array}$ \\
\hline $\begin{array}{l}\text { IoT enabled } \\
\text { digital energy } \\
\text { meters }\end{array}$ & $\begin{array}{l}\text { Energy quality parameters } \\
\text { measurement and remote } \\
\text { access of meter data for } \\
\text { analysis }\end{array}$ & $\begin{array}{l}\text { Real-time access to changes in } \\
\text { energy parameters enabled } \\
\text { predictive and preventative } \\
\text { maintenance; Accurate } \\
\text { identification of electrical } \\
\text { problems in specific electrical } \\
\text { lines and equipment; Reduction } \\
\text { of entire plant shut down to } \\
\text { locate faults; Allocate energy }\end{array}$ & $\begin{array}{c}\text { WIP } \\
\text { manufacturing } \\
\text { with plant } \\
\text { reliability }\end{array}$ \\
\hline
\end{tabular}




\begin{tabular}{|c|c|c|c|}
\hline & & $\begin{array}{l}\text { usage to unit cost of } \\
\text { manufactured product }\end{array}$ & \\
\hline 3D printing & $\begin{array}{l}\text { Product innovation with } \\
\text { specific focus on bottle } \\
\text { parameters for marketing and } \\
\text { functionality within } \\
\text { manufacturing environment; } \\
\text { Cost reduction in inventory } \\
\text { management; Spare parts } \\
\text { replacement for timely repairs } \\
\text { or unsupported equipment }\end{array}$ & $\begin{array}{l}\text { Current stage is in evaluating the } \\
\text { costs for implementation vs the } \\
\text { perceived ROIs using the } \\
\text { framework in Figure } 25\end{array}$ & $\begin{array}{l}\text { WIP design with } \\
\text { B2C Consumer }\end{array}$ \\
\hline $\begin{array}{c}\text { GPS fleet } \\
\text { management }\end{array}$ & $\begin{array}{l}\text { Monitor and create alerts for } \\
\text { sales vehicles along planned } \\
\text { routes; Future: Enhancements } \\
\text { as monitoring of cab's video } \\
\text { and audio for safety, Cooler } \\
\text { environment monitoring for } \\
\text { product quality, Tracking } \\
\text { product inventory }\end{array}$ & $\begin{array}{l}\text { Determine route profitability to } \\
\text { allocate additional resources to } \\
\text { service existing and new } \\
\text { customers; Identify unplanned } \\
\text { vehicle stops to obtain driver } \\
\text { justification }\end{array}$ & $\begin{array}{l}\text { Final Product } \\
\text { with B2B } \\
\text { Consumer }\end{array}$ \\
\hline $\begin{array}{l}\text { CRM social } \\
\text { media } \\
\text { integration }\end{array}$ & $\begin{array}{l}\text { Evaluate social media feeds } \\
\text { for negative keywords related } \\
\text { to organisation, operations } \\
\text { and products; Future: } \\
\text { Automatic integration with } \\
\text { ERP platform }\end{array}$ & $\begin{array}{l}\text { Customer feedback mechanism } \\
\text { to identify and solve specific user } \\
\text { issues; Identify and exploit } \\
\text { opportunities based upon } \\
\text { comments }\end{array}$ & $\begin{array}{l}\text { Final Product } \\
\text { with both B2B } \\
\text { and B2C } \\
\text { consumers }\end{array}$ \\
\hline $\begin{array}{c}\text { Cloud } \\
\text { infrastructure }\end{array}$ & $\begin{array}{c}\text { Store critical systems on } \\
\text { hardware off site in both local } \\
\text { data centres and the Cloud }\end{array}$ & $\begin{array}{l}\text { Disaster recovery, backup and } \\
\text { remote access; Cloud security } \\
\text { and access to Cloud based } \\
\text { features; Outsourced non-value } \\
\text { added items }\end{array}$ & $\begin{array}{c}\text { Enables } \\
\text { integration } \\
\text { between all } \\
\text { value networks } \\
\text { through Cloud } \\
\text { access }\end{array}$ \\
\hline
\end{tabular}

Table 33: EduColCom Technology Adoption

\begin{tabular}{|c|c|c|c|}
\hline Technology & Purpose & Benefits & Integration \\
\hline $\begin{array}{l}\text { Amazon } \\
\text { Alexa } \\
\text { assistant }\end{array}$ & $\begin{array}{l}\text { Understanding natural } \\
\text { language forms of questions; } \\
\text { Ability to trigger other event } \\
\text { conditions as chat bots }\end{array}$ & $\begin{array}{c}\text { Provide easier } \\
\text { communication interface } \\
\text { between students and } \\
\text { information repositories }\end{array}$ & $\begin{array}{l}\text { Student integrated with } \\
\text { knowledge base } \\
\text { repository at all value } \\
\text { networks from Raw } \\
\text { materials to Final product }\end{array}$ \\
\hline Chatbots & $\begin{array}{l}\text { Reliable connectivity allows } \\
\text { students to quickly and easily } \\
\text { receive answers to common } \\
\text { questions } 24 / 7 \text {; Future: } \\
\text { Enable student to access own } \\
\text { confidential information }\end{array}$ & $\begin{array}{l}\text { Reduce student negative } \\
\text { perceptions and } \\
\text { complaints due to lack of } \\
\text { communication and } \\
\text { difficulty finding answers }\end{array}$ & $\begin{array}{l}\text { Student integrated with } \\
\text { knowledge base } \\
\text { repository at all value } \\
\text { networks from Raw } \\
\text { materials to Final product }\end{array}$ \\
\hline $\begin{array}{c}\text { Proximity } \\
\text { beacons }\end{array}$ & $\begin{array}{l}\text { Push notifications to } \\
\text { registered phones }\end{array}$ & $\begin{array}{l}\text { Students receive relevant } \\
\text { time-dependent messages } \\
\text { as key reminders for }\end{array}$ & $\begin{array}{l}\text { Student integrated with } \\
\text { knowledge base } \\
\text { repository at all value }\end{array}$ \\
\hline
\end{tabular}




\begin{tabular}{|c|c|c|c|}
\hline & & $\begin{array}{l}\text { specific actions based on } \\
\text { beacon location }\end{array}$ & $\begin{array}{l}\text { networks from Raw } \\
\text { materials to Final product }\end{array}$ \\
\hline AI responses & $\begin{array}{l}\text { Intelligent responses to } \\
\text { unplanned student questions }\end{array}$ & $\begin{array}{l}\text { Understand the intent of } \\
\text { the student question to } \\
\text { provide safe and accurate } \\
\text { recommendations }\end{array}$ & $\begin{array}{l}\text { Student integrated with } \\
\text { knowledge base } \\
\text { repository at all value } \\
\text { networks from Raw } \\
\text { materials to Final product }\end{array}$ \\
\hline $\begin{array}{c}\text { Cloud } \\
\text { infrastructure }\end{array}$ & $\begin{array}{c}\text { Store critical systems on } \\
\text { hardware off site in both local } \\
\text { data centres and the Cloud }\end{array}$ & $\begin{array}{c}\text { Disaster recovery, backup } \\
\text { and remote access; Cloud } \\
\text { security and access to } \\
\text { Cloud based features; } \\
\text { Outsourced non-value } \\
\text { added items }\end{array}$ & $\begin{array}{c}\text { Enables integration } \\
\text { between all value } \\
\text { networks through Cloud } \\
\text { access }\end{array}$ \\
\hline $\begin{array}{l}\text { Student } \\
\text { payment } \\
\text { pipeline }\end{array}$ & $\begin{array}{l}\text { Enable online payment at any } \\
\text { time via student ID access; } \\
\text { Real-time update of received } \\
\text { funds }\end{array}$ & $\begin{array}{l}\text { Flexible and reliable } \\
\text { portal for remote payment } \\
\text { of fees ensuring timely } \\
\text { registration for courses }\end{array}$ & $\begin{array}{l}\text { Financial transactions } \\
\text { linked with ERP financial } \\
\text { module and student } \\
\text { registration }\end{array}$ \\
\hline
\end{tabular}

Table 34: Company Technologies linked to I4.0 Enabling Technologies

\begin{tabular}{|c|c|}
\hline $\begin{array}{c}\text { Company identified } \\
\text { technology }\end{array}$ & Linked I4.0 Enabling Technology \\
\hline Virtual Reality headsets & $\begin{array}{c}\text { Data mining; Augmented reality and wearables; Big Data analytics and } \\
\text { advanced algorithms; System integration; Simulation; Smart sensors; } \\
\text { Advanced human-machine interfaces; Location detection technologies }\end{array}$ \\
\hline $\begin{array}{c}\text { IoT enabled digital } \\
\text { energy meters }\end{array}$ & $\begin{array}{c}\text { Internet of Things (IoT) platforms; Cloud computing; Big Data analytics } \\
\text { and advanced algorithms }\end{array}$ \\
\hline 3D printing & Additive manufacturing and 3-D printing; Simulation \\
\hline GPS fleet management & Location detection technologies; System integration; Data mining \\
\hline $\begin{array}{c}\text { CRM social media } \\
\text { integration }\end{array}$ & $\begin{array}{c}\text { Multilevel customer interaction and customer profiling (community); } \\
\text { System integration; Big Data analytics and advanced algorithms }\end{array}$ \\
\hline $\begin{array}{c}\text { Cloud infrastructure } \\
\text { Cloud computing }\end{array}$ & $\begin{array}{c}\text { System integration; Cybersecurity, authentication and fraud detection; } \\
\text { Amazon Alexa assistant }\end{array}$ \\
$\begin{array}{c}\text { Machine learning; Cloud computing; Data Mining; Big Data analytics and } \\
\text { advanced algorithms; Autonomous robots; System integration; Internet of } \\
\text { Things (IoT) platforms; Multilevel customer interaction and customer } \\
\text { profiling (community) }\end{array}$ \\
\hline Chat bots & Data mining; Autonomous robots \\
\hline Proximity beacons & Mobility technologies (mobile devices); Location detection technologies \\
\hline AI responses & $\begin{array}{c}\text { Machine learning; Cloud computing; Data Mining; Big Data analytics and } \\
\text { advanced algorithms }\end{array}$ \\
\hline $\begin{array}{c}\text { Student payment } \\
\text { pipeline }\end{array}$ & Cybersecurity, authentication and fraud detection \\
\hline
\end{tabular}

The emerging technologies assisted the SMEs to be developmentally ready for I4.0. However, improvements should be focused in areas of integration of value chains, connected systems and intelligent [systems] ( 
). Cloud platforms facilitate these changes as each SME adopts more of its features.

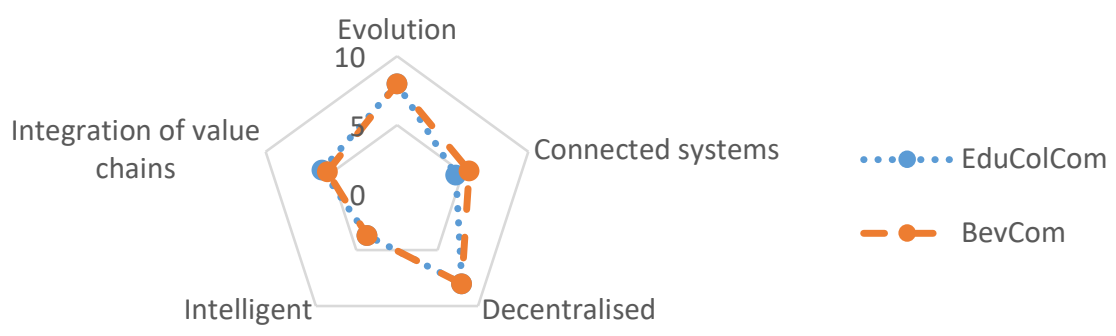

Figure 24: I4.0 Relative Readiness of EduColCom and BevCom

Each SME's relative value was determined by the combination of an averaged value of their key concept, based on its specific linkages to the I4.0 design principles (section 2), and a qualitative comparative assessment of each SME based on their I4.0 drivers and challenges as well as facility tours [6 p. 17]. Value of 10 was used to illustrate the full I4.0 concept and 0 denoted it was neither started nor considered [19 p. 97]. EduColCom scored higher in concepts of integration and awareness and BevCom was higher in communication, which improved their overall connected system concept.

\section{Evolution Roadmaps}

In the BevCom process (Figure 25), each decision factor is matched to an appropriate I4.0 technology to satisfy the factor's requirements. The specific tool is evaluated on costs as well as value generated to determine the potential of investment in a proof of concept $(\mathrm{PoC})$ that would enable the organisation to practically determine the true effects, whilst reducing the risk involved in a plant-wide adoption. In this method, vertical and horizontal integrations are based on value need as well as an understanding and acceptance that new technology benefits are unproven until implemented and used. Their assessment is continuous as they operate in a dynamic environment of varying consumer requests, evolving competitors, and fluctuating availability and costs of raw materials. This promotes evolution.

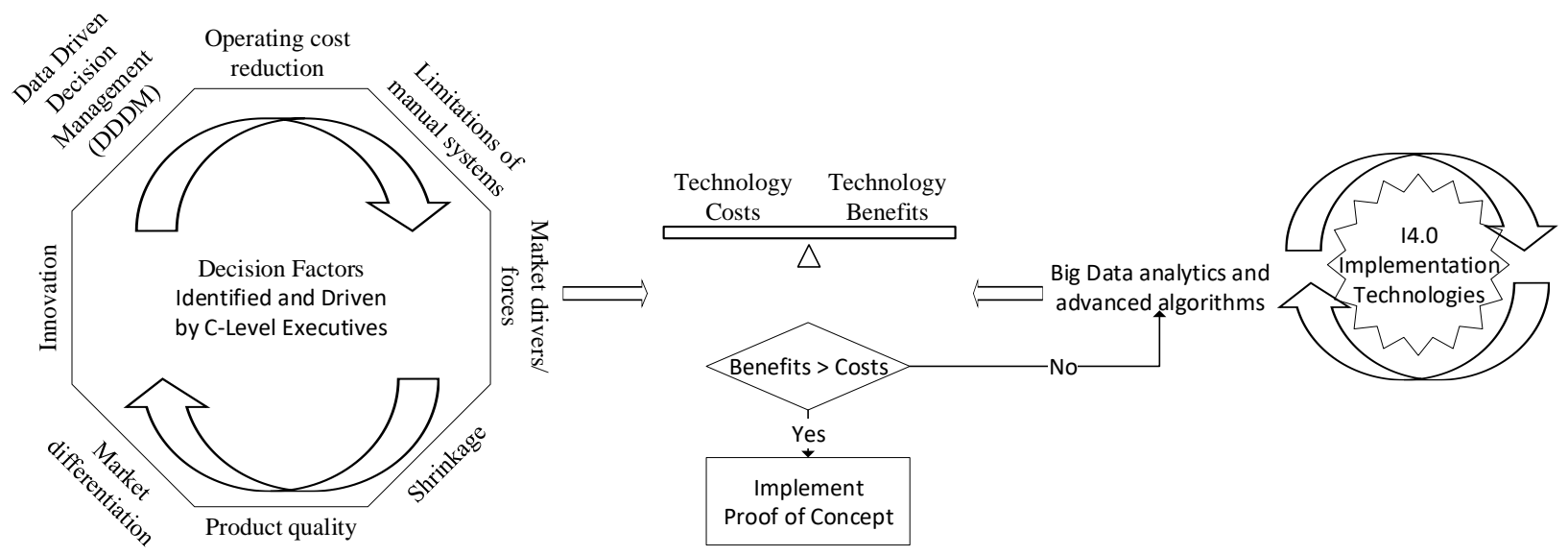


Figure 25: BevCom Decision Factors Linked to Technology ROI

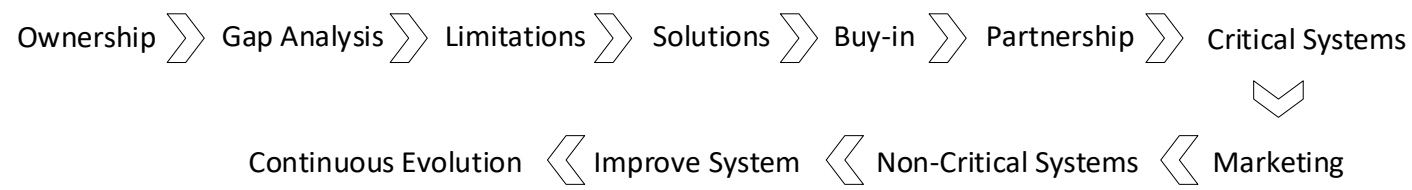

Figure 26: EduColCom Decision Steps

EduColCom utilised a segmented approach summarised as sequential steps (Figure 26). The focus on critical systems before progressing to the next phase (improvement and evolution) ensured a successful transformation. It started with the C-level executive accepting ownership of the situation and performing a gap analysis to understand the system inefficiencies and potential opportunities to strengthen integrations. Identification of limitations (financial, technology, experienced staff) framed the needed solutions advised by the technology vendor. Buy-in from the stakeholders was accomplished by discussing problems and solutions to provide a unified approach to the problems. Horizontal integration with the technology provider created a partnership that enabled costs reduction in exchange for EduColCom being a test case $(\mathrm{PoC})$. The stability of critical systems and its marketing encouraged easier and faster adoption of the changes. This enabled them to focus on continuous improvements by evaluating non-critical systems and trouble areas that the implemented technology would solve. These changes facilitate evolution.

EduColCom's horizontal integration with a technology vendor may not be available for all SMEs. Thus, a similar approach is the formation of an I4.0 cluster group with other non-competitive SMEs in which each would benefit from the sharing of the resources and costs amongst one other [19 pp. 122-129; 20 p. 54; 21 pp. 14-15].

Each strategic roadmap was compared in Table 35. The specifics of their approach varied due to the stability (or instability) of their systems, thus highlighting two pathways for evolution.

Table 35: Key differences in strategic roadmaps used by EduColCom and BevCom

\begin{tabular}{|c|c|c|}
\hline Factors & EduColCom: Unstable system & BevCom: Stable system \\
\hline Primary goal & Identify and stabilise critical systems & Continuous improvement and evolution \\
\hline Sequence & $\begin{array}{l}\text { Linear segmented progression of } \\
\text { processes (each step dependent upon } \\
\text { its predecessor) }\end{array}$ & $\begin{array}{l}\text { Iterative matching of selected decision factors } \\
\text { (priority given to the highest cost factors of } \\
\text { the production environment) with } 14.0 \\
\text { enabling technologies }\end{array}$ \\
\hline $\begin{array}{l}\text { System } \\
\text { development }\end{array}$ & $\begin{array}{l}\text { Cloud based systems ( } \\
\text { Table 33) and partnership with } \\
\text { technology vendor selected due to } \\
\text { financial limitations and insufficient } \\
\text { experienced personnel }\end{array}$ & $\begin{array}{l}\text { Technologies (Table 32) to continuously } \\
\text { drive the organisation to remain competitive, } \\
\text { via value generation, reduction of costs } \\
\text { (including inefficiencies) and disruption }\end{array}$ \\
\hline Adoption & $\begin{array}{l}\text { Continuous implementation and use } \\
\text { through marketing until stability of } \\
\text { systems achieved }\end{array}$ & $\begin{array}{l}\text { PoCs evaluated before full implementation } \\
\text { facilitated lower risk and smaller investments } \\
\text { to reduce impact to the entire plant and } \\
\text { manage change }\end{array}$ \\
\hline
\end{tabular}

\section{Conclusion}

In each strategy support at the C-level is a key driving force for evolutionary change to achieve innovation, competitiveness and sustainability through the implementation of I4.0 enabling technology. 
EduColCom formed a horizontal integration with the technology vendor to stabilise their system as well as improve their services for the students. An alternate option is the formation of an I4.0 cluster, with noncompetitive entities, to enable sharing of resources and reduction of procurement costs through economies of scale.

The value is in the choice of strategy to initiate and maintain evolution. EduColCom utilised a segmented approach that started with the C-level executive accepting ownership of the situation, securing buy-in from the stakeholders, horizontally integrating with the technology provider and stabilising the system before focusing on continuous improvements. BevCom's approach was based on a stable system and driven by decision factors identified and supported by C-level executives. Each factor was paired with a specific technology to satisfy the requirements, then a cost vs benefit evaluation determined whether a PoC would be implemented to test the validity of the change before consideration of a wider plant adoption.

\section{References}

[1] Sniderman, B., Mahto, M., Cotteleer, M.J.: 'Industry 4.0 and manufacturing ecosystems Exploring the world of connected enterprises' (2016)

[2] Vogel-Heuser, B., Hess, D.: 'Guest Editorial Industry 4.0-Prerequisites and Visions'IEEE Trans. Autom. Sci. Eng., 2016, 13, (2), pp. 411-413.

[3] Qina, J., Liua, Y., Grosvenora, R.: 'A Categorical Framework of Manufacturing for Industry 4.0 and Beyond'Procedia CIRP, 2016, 52, (2016), pp. 173-178.

[4] Schwab, K.: 'The fourth industrial revolution' (Crown Publishing Group, 2016, First)

[5] Philbeck, T., Davis, N.: 'The Fourth Industrial Revolution: Shaping a New Era' J. Int. Aff., 2019, 72, (1), pp. 17-22.

[6] Rameshwar, J.R., King, G.S.: 'Developmental Requirements Implementing Industry 4.0 in Trinidad and Tobago Companies'J. Assoc. Prof. Eng. Trinidad Tobago, 2019, 47, (2), pp. 11-19.

[7] Sherwin, P.: 'Industry 4.0 + IIoT = Smart Industrial Ovens \& Furnaces'Process Heat., 2016.

[8] Prause, M., Weigand, J.: 'Industry 4.0 and Object-Oriented Development - Incremental and Architectural Change'J. Technol. Manag. Innov., 2016, 11, (2), pp. 104-110.

[9] KUKA Aktiengesellschaft: 'Hello Industry 4.0_we go digital' (2016)

[10] VDI/VDE-Gesellschaft für Mess- und Automatisierungstechnik: 'Status Report Reference Architecture Model Industrie 4.0 (RAMI4.0)' (2015)

[11] Roblek, V., Meško, M., Krapež, A.: 'A Complex View of Industry 4.0'SAGE Open, 2016, AprilJune, pp. 1-11.

[12] Heng, S.: 'Industry 4.0 Upgrading of Germany's industrial capabilities on the horizon' (2014)

[13] Wernicke, I.H.: 'Achieving Sustainable Economic Growth from the European Point of View'J. Econ. Dev. Manag. IT, Financ. Mark., 2015, 7, (2), pp. 1-23.

[14] Ramanathan, K.: 'Industry 4.0 - Implications for the Asia Pacific Manufacturing Industry' SMT Surf. Mt. Technol., 2015.

[15] Geissbauer, D.R., Vedso, J., Schrauf, S.: 'Industry 4.0: Building the digital enterprise' (2016)

[16] Bagheri, B., Yang, S., Kao, H.-A., et al.: 'Cyber-physical Systems Architecture for Self-Aware Machines in Industry 4.0 Environment' IFAC (International Fed. Autom. Control., 2015, 48, (3), pp. 1622-1627.

[17] MacDougall, W.: 'INDUSTRIE 4.0 Smart Manufacturing for the Future' (2014)

[18] CFE Media: '2016 Digital Report IIoT' (2016)

[19] Rameshwar, J.R.: 'Getting Ready for Industry 4.0 in Trinidad and Tobago: An Assessment of Developmental Requirements of Case Study Companies'. MSc. Thesis, The University of the West Indies, 2017

[20] Rameshwar, J.R., King, G.S.: 'Developmental Requirements for Implementing Industry 4.0 in Trinidad and Tobago Companies', in Pun, K.F. (Ed.): 'The IEM4-2018 Conference: Striving for performance excellence with quality management and IEM practices' (Faculty of Engineering, The 
University of the West Indies, 2018), pp. 48-56

[21] King, G.S., Rameshwar, J.R.: 'Stimulating Innovation through Industry 4.0 in a Small CommodityBased Economy', in '2017 ISPIM Innovation Summit (Melbourne) Presentation' (2017)

[22] Moustapha, H.: 'Aerospace 4.0' (2016)

[23] Zhan, Z.-H., Liu, X.-F., Gong, Y.-J., et al.: 'Cloud Computing Resource Scheduling and a Survey of Its Evolutionary Approaches'ACM Comput. Surv., 2015, 47, (4), pp. 1-33.

[24] Bechtold, J., Lauenstein, C., Kern, A., et al.: 'Industry 4.0 - The Capgemini Consulting View Sharpening the Picture beyond the Hype' (2016)

[25] Gartner: 'Hype Cycle Research Methodology', https://www.gartner.com/en/research/methodologies/gartner-hype-cycle, accessed May 2019

[26] Panetta, K.: 'Gartner Top 10 Strategic Technology Trends for 2019', https://www.gartner.com/smarterwithgartner/gartner-top-10-strategic-technology-trends-for-2019/, accessed May 2019

[27] Vogel-Heuser, B., Rösch, S., Fischer, J., et al.: 'Fault Handling in PLC-Based Industry 4.0 Automated Production Systems as a Basis for Restart and Self-Configuration and Its Evaluation'J. Softw. Eng. Appl., 2016, 09, (01), pp. 1-43.

[28] Xu, L. Da, Xu, E.L., Li, L.: 'Industry 4.0: state of the art and future trends'Int. J. Prod. Res., 2018, 56, (8), pp. 2941-2962.

[29] Syan, C.S., Ramoutar, K.: 'Impact of Company Size on Manufacturing Improvement Practices - An empirical study'IOP Conf. Ser. Mater. Sci. Eng., 2014, 65, (2014), pp. 1-8.

[30] Syan, C., Ramoutar, K.: 'Assessment of the Status of the Manufacturing Industry in Trinidad and Tobago and the Caribbean', in '24th International Conference on CAD/CAM, Robotics and Factories of the Future At: Koriyama, Japan, June 2008' (2008)

[31] Pun, K.F., Jaggernath-Furlonge, S.: 'Impacts of company size and culture on quality management practices in manufacturing organisations'TQM J., 2012, 24, (1), pp. 83-101. 